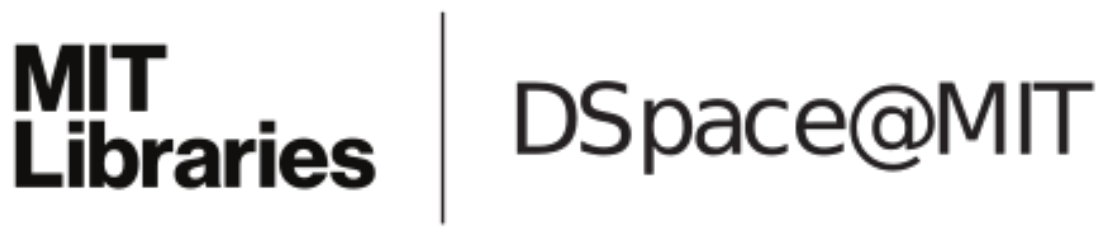

\author{
MIT Open Access Articles
}

Actual and potential gifts: Critique, shadow gift relations and the virtual domain of the ungiven

The MIT Faculty has made this article openly available. Please share how this access benefits you. Your story matters.

Citation: Copeman, John and Dwaipayan Banerjee. "Actual and potential gifts: Critique, shadow gift relations and the virtual domain of the ungiven. " Anthropological Theory : 1-22 ๔ 2020 The Author(s)

As Published: http://dx.doi.org/10.1177/1463499619894426

Publisher: SAGE Publications

Persistent URL: https://hdl.handle.net/1721.1/123839

Version: Author's final manuscript: final author's manuscript post peer review, without publisher's formatting or copy editing

Terms of use: Creative Commons Attribution-Noncommercial-Share Alike 


\title{
Actual and potential gifts: Critique, shadow gift relations and the virtual domain of the ungiven
}

\author{
with Jacob Copeman
}

\section{Anthropology Theory}

\begin{abstract}
:
What is given may be evaluated in relation to what might have been given but was not. The central thematic of this essay is what we term the shadow gift relation (as distinct from the more standard anthropological gift relation among exchange partner dyads) between the gift that is given and that which remains ungiven -- with the latter, both present and not present, coming to haunt and unsettle the former. The potential of the gift is key for it is intimately related to critique: we explore how the relation between the virtual ungiven and what is actually given may come to form the basis of social criticism. This essay, then, defines a kind of 'keeping while giving' that is related to but different from that famously elaborated by Annette Weiner, for what is kept back, in the cases we discuss in this essay, are virtual (imagined) forms of gift. Giving is a technology of the imagination because it is a process which precipitates the imagination of a relation between an actual gift and a double that is virtual but nonetheless real because it exists in the form of a manifold of potentials for how the gift could be.
\end{abstract}

\section{Keywords:}

critique, temporality, gift, potential, philanthropy, charity, hauntology, shadow gift relation

\section{Introduction}

In 2010 the novelist Howard Jacobson won the UK's most prestigious book prize competition, the Man Booker Prize, for his novel The Finkler Question. Although it was his first win, it was not the first time he had been nominated. Accepting the award, Jacobson said: 'I'm speechless. Fortunately, I prepared one earlier. It's dated 1983. That's how long the wait's been. And I see here that there's another altered acceptance speech from 1994, then 2002, which I appear to have amended only slightly for 2004, 2006 and 2008. I note that my language in these speeches grows less gracious with the years. You start to want to blame the judges who have given you the prize for all the prizes they didn't give you.... they aren't of course the same judges. Tonight, I forgive everyone. They were only doing their job, those judges, every one of whose names I could reel off. And as for the judges of the 2010 Man Booker Prize, they surpass all praise. I thank them' ${ }^{1}$

\footnotetext{
${ }^{1}$ See https://www.youtube.com/watch?v=Zj_IXwSf2CY
} 
Jacobson, while clearly delighted, acknowledges and gives bittersweet voice to the pathos associated with those previous times he was nominated for but not awarded the prize: those 'might have been' honours. What he was given - the prize that he was awarded in actuality - is evaluated, with humour and pathos, in relation to the prizes he might have won, but did not. Indeed, Jacobson's concern with unawarded prizes, even in the moment of his triumph, points us towards the central thematic of this essay, which is what we term the shadow gift relation (as distinct from the more standard anthropological gift relation among exchange partner dyads). The shadow gift relation is the relation that is conjured in specific forms of commentary on the gift between the gift that is given and that which remains ungiven. The latter, both present and not present, may come to haunt and unsettle the former. Such a relation may (be made to) form a relation of critique. It is this relation that we seek to draw out in this essay.

To consider such shadow gift relations is to consider gifts in terms of how what is given is conceptually only one element of what might have been given. Thus, the potential of the gift is at the heart of our analysis. Consequently, so is critique. We explore how the relation between the virtual, ungiven totality (from which the given element is obtained) and what is actually given may come to form the basis of social criticism. We treat the virtual and the potential here as mutually implicated: in this we follow Jon Bialecki's (2012: 307) reading of Deleuze's (Deleuze and Parnet 2007: 148-52) concept of the virtual 'as a way of speaking about an unquantifiable field of generative potential in being and thought, a potential intelligible yet specifically undeterminable in advance of development'. We develop this concept of the virtual with the caveat that though the field of the gift's generative potential is indeed objectively unquantifiable and undeterminable, it can still be imagined. Indeed, we treat the gift as a technology of the imagination since the gift is a key 'social and material means by which particular imaginings are generated' (Sneath, Holbraad and Pedersen 2009: 6) - a concrete process engendering 'the ability to bring to mind that which is not entirely present to the senses' (ibid: 12) - namely, in this essay, a gift's shadow or virtual form as a field of generative potential. The ungiven, then, defines a kind of 'keeping while giving' that is related to but different from that famously elaborated by Annette Weiner $(1985,1992)$, for what is kept back, in the cases we discuss here, are virtual forms of gift. Weiner, as is well known, discloses classes of inalienable possessions: those which are never exchanged and those that are exchanged but remain connected to their real owners (1985: 212). Like Weiner, we are interested less in the relation between exchange partners than that between the given and the withheld. But if Weiner's treatment of this problem was through the lens of their relative alienability or inalienability, and ours through that of their relative proportions (and moral evaluations thereof), both projects seek to show that the relationship between exchange partners is far from being all that matters in gift-giving.

Drawing on the insights of economic anthropologist John Davis (1992), Alberto Corsín Jiménez focuses on partonomies in and out of balance in material exchanges, observing that 'the part that we give is an indication of the whole that is not given - what you see (the gift) is what you do not get (the larger social whole). Gift-giving is thus an expression and effect 
of proportionality' (2008: 186). ${ }^{2}$ We note that Davis (1992: 39) emphasised the socially defined nature of partonomies which depend on 'local criteria of relevance: they are not scientific or objective'. This should be borne in mind when we refer to 'wholes': they are an aspect of the imagination -- the image one has of the (size of) resources available to an entity for giving. In fact, rather than 'whole' we might prefer the terms 'entity' or 'phenomenon' (Thornton 2017). If we continue to refer to 'wholes' in our analysis, it is not as a pre-determined entity, but rather as a kind of virtuality. The gift emerges as a kind of actor here, but not in the classic Maussian sense by means of containing and extending the animate personhood of its giver. Rather, gifts comment on their own pathos in demonstrating limits and constraints in commitment and largesse and embodying their critique ('what you see (the gift) is what you do not get'). Following from this, to enable a proportional perspective on the gift is to view it as always part of noetic 'could be'-offerings that can be made to produce critical effects: if gift-giving is an expression and effect of proportionality, the proportions of the gift are subject to moral evaluations and demands. The gift is a portion or element, but an element of what? The simplest answer would be: the imagination. We note that a shadow gift relation may take not only a proportional form but also a taxonomic one: a gift's can be or might have been other can equally be a question of order as proportions. Our focus, which is mainly on the latter, is a function of the casestudies we have had to hand rather than a conceptual point of order.

Since our focus is on how divergences between the gift that is given and the multitude of unpotentiated, ungiven gifts can come to form the basis of critical social commentary, this essay forms part of a growing body of work in anthropology on techniques and practices of critique (Boland 2013a, Bialecki 2018, Copeman 2018, cf. Boltanski 2010) by offering new perspectives on critical forms of giving. 'Critical' because the ungiven gift, as the negative Other of the given, is capable of stimulating critical commentary on that which is actually proffered. Since such a relation is invisible but imaginable, and at the same time not the kind of gift relation usually considered by anthropologists, we term it a shadow gift relation.

We do not at all suggest that this relation and its critical function is all that matters in acts of giving. Our aim is simply to open up other aspects of giving: not seeking to advance a critique of theories of the gift but to understand how the gift itself critiques. ${ }^{3}$ Further, our concern is less with the kind of gift-giving that entails obvious signs of reciprocity or sense of a cycle than it is with contributions made in order 'to support the upliftment of individuals and communities [...] that might be glossed as expressive of charitable or philanthropic dispositions' (Osella 2018: 8); what Maurice Godelier (1999: 5) has called the 'modernised' gift, which if it creates a bond at all is one that is 'between abstract subjects'. Of course, no neat distinction exists between the charitable gift and the 'gift that makes friends' (Mauss's

\footnotetext{
2 Partonomies are hierarchies of part-whole relationships, often contrasted with 'kind of' taxonomic relations: these 'two modes of decomposition reflect two general forms of organization of knowledge, taxonomic, that is, subdivision into kinds, and partonomic, that is, subdivision into parts' (Tversky 1989: 983).

${ }^{3}$ While charitable giving may critique quite conventionally in the sense of drawing attention to the human suffering it usually seeks to repair (a kind of critique by default or implication), this point does not apply to all 'philanthropic' acts. For example, the feeding of the poor in temples in India or the giving of alms does not necessarily wage a critique of suffering, but instead may take suffering as a condition of the world, and an opportunity for the exercise of dharma. Here, suffering is naturalized, not critiqued.
} 
foundational text was after all 'an exploration of the paradoxical character of the gift' [Laidlaw 2000: 620]), and Godelier's modernised gift may not be so modern after all, given its overlaps and parallels with longstanding gift modalities in various local contexts (Osella 2018: 8). Nevertheless, the sorts of gift that 'create, maintain and strengthen various social bonds' (Yan 2005: 246) are not our main focus, even if the concepts we explore may be revealingly applied to them. One could object: most actions carry with them the ghosts of their unfulfilled alternatives, and everything potentially is something else. That may be the case, but gifts, and especially material transfers of wealth performed unilaterally with the professed intention of alleviating suffering (viz. philanthropic and/or charitable gifts), are particularly subject to moral evaluation in relation to what could have been done in place of what is actually done.

The shadow gift relation may be expressed in terms of the hauntedness of the gift. The actualized gift possesses a kind of 'as if', noetic dimension -- an imaginative space teeming with alternatives to the actually given gift. ${ }^{4}$ Haunted by those alternatives, the gift can come to appear 'beside itself, disadjusted' (Derrida 1993: 20). Our point, following Derrida's 'hauntological' explorations, is simply that the gift is scarcely as obviously itself as it might seem. ${ }^{5}$ If our language of ghostly and phantom gifts might appear to be over-stating the matter, we will see quite literally in one of our case studies how the ungiven gift may be made to equate with unsaved lives.

Significantly, the actually given gift is frequently subject to comparison along an axis of possibilities and potentials as a form of rhetoric. Virtual comparisons are formed between the actualised instance and its could be or could have been counterparts. We are concerned here with moral evaluation of giving episodes. Like us, Nikolai Ssorin-Chaikov and Olga Sosnina (2004) focus less on the problematic of reciprocity than on the rhetorical properties of giving. Gifts demonstrate 'facts' - 'matters of fact' are demonstrable through the giving of 'facts of matter'. Gifts operate (are evaluated) as figures of commitment. A gift may demonstrate commitment, but if its proportional structure is 'off-kilter' (say, Jeff Bezos offers only a single dollar to a beggar), then it may, of course, signal the very opposite. Is the level of a donation 'appropriately compassionate' (Berlant 2004: 10) given what we think we know about the resources available to the donor in question? What is being withheld even as a gift is given? This is to say, public donations invite comments and assessment; they are taken to demonstrate something. Demonstration necessitates an act of witnessing with two dimensions: 'The first implies proof: by performing evidence for an audience, the truth of a hypothesis is demonstrated. The second, associated with a "demo", displays a not yet actualized real object, by showing what is possible' (Kelly 2003: 35). Proceeding from this, we explore below how actual gifts can come to possess qualities of the prototype. Ann Kelly's insight here, in tandem with the viewpoint proposed by Ssorin-Chaikov and Sosnina, allows us to observe the bifocal temporality of a gift understood hauntologically: looking

\footnotetext{
${ }^{4}$ A paraphrase of Amsterdam and Bruner (2000: 237).

${ }^{5}$ See Frederic Jameson's helpful gloss: '[Hauntological] spectrality does not involve the conviction that ghosts exist or that the past (and maybe even the future they offer to prophesy) is still very much alive and at work, within the living present: all it says, if it can be thought to speak, is that the living present is scarcely as selfsufficient as it claims to be; that we would do well not to count on its density and solidity, which might under exceptional circumstances betray us' (Jameson 1999: 39).
} 
backwards towards what might have been given, and forwards to what might still be given. The gift comes into view as a species of rhetoric and commentary (to which it is also subject), the discursive purchase of which arises from the imagined relation between the actually given and an ungiven that haunts it.

The (un)given gift as a subject of moral deliberation of course recalls recent debates in the anthropology of ethics, and much more longstanding ones in moral philosophy, concerning the relation between 'is' and 'ought' (Beldo 2014). As John Ladd (1957: 86) perspicuously remarked: 'We do not think it possible for a person to be obligated to do something outside his power... This follows from the generally acknowledged principle that in some sense "ought" implies "can.'" Indeed, the kinds of 'otherwise-' - or, indeed, 'ought-' - gift we discuss in this essay only become intelligible in this light, with the imagined capacities of givers of course central to the sorts of commentary and evaluation attracted by gift transfers. If the giver of an actual gift is considered to be without the means of giving an alternative version of it, then an 'ought'-gift is unintelligible. Only where the possibility of a different gift exists do 'can' and 'ought' come into play with, to reverse Ladd's formulation, 'can' coming logically to imply 'ought'. This can be problematic - as when the 'can' of giving a kidney (the medical possibility of doing so) seems to pass into an obligation to do just that; what we call, adapting Sharon Kaufman's (2013) terminology, the tyranny of the potential gift. But equally, identifying unrealized giving potentials can be efficacious in holding people and institutions to account; i.e. in forming the basis of moral critique of inadequate or undelivered 'is' (i.e. actual) gifts. ${ }^{6}$

\section{Foreign Aid and Philanthropy}

In this section we consider contemporary debates about: (i) the proportions of a country's spending on foreign development aid, and (ii) high-profile philanthropic donations. We see in each case that the debates are animated by proportionally informed evaluations, or a 'proportional ethics' (Corsín Jiménez 2008), that critically frame philanthropy and aid gifting as problematics of the ungiven. The perspective we develop sees actualised gifts of aid and/or philanthropy as disturbed and unsettled by their own virtual ungiven forms.

To begin with international aid: The proportion spent by the UK on overseas development aid (ODA) is currently $0.7 \%$ of national income (i.e. for every ten pounds that is made in the UK, $7 p$ goes towards foreign aid). For David Cameron's conservative government (20102016), reaching a target of $0.7 \%$ was a flagship policy, and once reached, a move was made to enshrine it in law, and it is now legally binding for a government to allocate a proportion of national income for this purpose no less than this figure. The commitment occasioned heated debate in part due to the UK recession that was concurrent with it, and the conservative government's 'austerity' policies which saw almost all other state funding allocations drastically diminish even as its foreign aid spending continued to rise in order to meet the $0.7 \%$ target. An online petition begun by the right-of-centre newspaper The Mail on Sunday, signed by more than 200,000 people, put it thus: 'Despite spending cuts at home

\footnotetext{
${ }^{6}$ Kaufman's formulation has its origin in Renee Fox and Judith Swazey's (1992) influential work.
} 
the Government is committed to hand over $0.7 \%$ of national income in overseas aid, regardless of need... UK handouts [therefore] will rise from current $£ 12 \mathrm{bn}$ to $f 16 \mathrm{bn}$ by 2020 . This is by far the highest rate of any G20 nation and is leading to huge waste and corruption'.7 As one would expect, however, many others lauded the increase in the state's 'gift of aid', with other newspapers publishing international league tables based on the different proportions of state income allocated. Such tables (circa. 2016) show the UK in $5^{\text {th }}$ place below Norway, Luxembourg, Sweden and Denmark, with Germany and the Netherlands in $6^{\text {th }}$ and $7^{\text {th }}$ places respectively. The United States is in $23^{\text {rd }}$ place, just above Portugal and Hungary. Such ranking exercises, even without further commentary, enact an overt critique of the countries with extremely low percentage allocations, with the United States, for instance, spending just $0.17 \%$ of its national income on overseas development aid. ${ }^{8}$ The UK was praised by Bill Gates for its '“absolutely fantastic' decision to [take the lead] in embrac[ing] the UN target of spending $0.7 \%$ of GNI (gross national income) on overseas aid by 2013'. ${ }^{9}$ On the other hand, 'even without Trump's proposed cuts [of a drastic $28 \%$ to its aid budget], [the] US fails to lead'. ${ }^{10}$ So far as the UK is concerned, then, a kind of anti-hauntology of the gift was generated since commentary focused not on the shadow side of the gift and attendant unsaved lives but rather on what had been given and the quantity of lives positively affected. For instance, the chief executive of the charity Save the Children praised Cameron for his role in organizing a conference - central to his ODA target figure commitment - on child vaccinations: 'Probably a million lives have been saved since Cameron called the vaccines summit [in June 2011]'. ${ }^{11}$

And yet, in the reader comments section below the online version of the newspaper article just cited, we find such responses as: 'What about our own children going hungry to school and parents having to rely on charitable foodbanks? Our elderly people having their care services cut... Our disabled people having to endure repeated medical tests so their disability benefits can be cut. All in the name of reducing the deficit'. Specifically in response to the byline 'Prime Minister says ahead of hunger summit that even in tough times it is right to help the world's poor and malnourished' we find the comment: 'Of course. Unless they're our own'. We see how shadow gift relations enact critique. For some, that which the UK gives in foreign aid brings into focus that which is ungiven in welfare spending within the UK. Meanwhile the very existence of gifts of food in the form of charitable food banks - the coming into existence of which almost exactly coincided with the beginning of Cameron's 'era of austerity' - enacts the critique of the stringent welfare cuts that makes their function so vital. If 'the rollback of the state has created levels of poverty last seen in the UK in the 1900s' (Thane 2018), it is the gift of food via food banks that makes the injustice of the state's welfare cuts for the most vulnerable most dramatically visible and therefore open to critique.

Turning to philanthropy: If on occasion the 'extreme' generosity displayed by various wealthy individuals can been taken to demonstrate the insufficiency of governments that

\footnotetext{
${ }^{7}$ https://petition.parliament.uk/archived/petitions/125692

${ }^{8} \mathrm{http}: / /$ theconversation.com/us-foreign-aid-explained-74810

${ }^{9}$ The Guardian, 13 June 2011.

${ }^{10} \mathrm{http}: / /$ theconversation.com/us-foreign-aid-explained-74810

${ }^{11}$ The Guardian, 10 Aug. 2012.
} 
cannot or do not give, evidencing lack of care for their vulnerable citizens (Osella 2018: 32), unsurprisingly the giving actions of wealthy individuals are equally open to partonomic and/or taxonomic critique. Take Jeff Bezos, founder of the Amazon corporation and reportedly the richest individual in history, who has been the subject of commentary highlighting a deficit in philanthropic commitment. Even after it was made public in 2019 that he was not only the world's wealthiest individual but also its biggest philanthropic benefactor, the news was met with faint praise. The Guardian's headline, for instance, read: 'World's richest man finally tops list of biggest donors' (emphasis added). ${ }^{12}$ If his charity now 'matched his wealth', well, better late than never. Prior to achieving this more adequate proportional 'match', his 'stingy reputation' had been much reported:

Bezos has long had a reputation for being unusually stingy, even for a multibillionaire. He is the only one of the world's top five billionaires not to have signed Warren Buffett's giving pledge [to donate half their wealth to philanthropic causes], and his philanthropic efforts so far have paled next to those of other prominent corporate titans like Bill Gates and even Mark Zuckerberg. Instead, he has used his money to purchase the largest luxury home in Washington DC (converting the $27,000 \mathrm{sq} f t$ Textile Museum into a single-family residence). Unlike his brother, Mark Bezos, a volunteer firefighter who runs an anti-poverty organization called Robin Hood, Jeff has confined himself to a few highly idiosyncratic forms of charity, such as handing out free bananas on the streets of Seattle. ${ }^{13}$

Bezos's acts of (not) giving are evaluated according to techniques of 'contrastive perception' (Suralles 2016). In addition to the cuttingly personal familial contrast with his sociallyminded brother, the proportions of their wealth allotted to philanthropic causes by similarly wealthy individuals are referred to as a means of contrastively contextualising the nature of his - i.e., their gifts are made to critique his via the mobilization of a contrastive proportional ethics. First, unlike Zuckerberg et al, we are informed that Bezos has failed to pledge half of his fortune to philanthropy. Second, even after he had gained the status of the world's single highest net donor, the proportion of his wealth donated relative to theirs was found to be wanting. In its comparative critique, The Daily Mail didn't mince its words:

Bottom of the table! Amazon CEO Jeff Bezos 'gives less than 0.1 per cent of his $\$ 160 b n$ fortune to charity' and is put in the shade by philanthropist Bill Gates, Mark Zuckerberg and President Trump.

- World's wealthiest man donated just 0.0906 per cent of his considerable wealth - Bill and Melinda Gates gave away 37 per cent of their fortune, figures show - Facebook's Mark Zuckerberg and his wife Priscilla Chan gave away four per cent and even President Trump donated three per cent of his $\$ 3$ billion fortune. ${ }^{14}$

It was not only The Daily Mail: proportional critique abounded. Take Vox: '\$2 billion is a meagre amount of money relative to the giving plans of other billionaires. He is committing

${ }^{12}$ The Guardian, 26 Feb. 2019.

${ }^{14}$ Daily Mail, 26 Feb. 2019. 
about 1.3 percent of his total net worth during a year in which his pocketbook doubled in size thanks to Amazon's bull run'. ${ }^{15}$ However, critique of Bezos's giving was based not only on a sense of its inadequate proportions but also on the matter of its kind. A Guardian article that offers Bezos advice on how he might 'change his stingy reputation' reports his use of Twitter to seek ideas for worthy philanthropic causes: 'He quickly received all manner of ideas from the public [in excess of 47,000 of them], ranging from paying off student loans to stopping climate change to building data centres in Africa. Some even proposed saving the actual Amazon'. ${ }^{16}$ However, if Bezos sought to imagine the 'kind' of his giving in accordance with philanthropic conventions associated with wealthy elites, the comment piece pointed out that 'If Bezos is looking for a population in need of his support, Amazon's workers perfectly fit the bill'; that is to say, the gift he seeks to give becomes an occasion for critique of labour conditions at the company he founded. There follows a long list of the ways in which Amazon workers across the world suffer from mental health issues, exhaustion, low pay and more. In this commentary, the spectral other of the gift Bezos sought to make (crowd-sourced, blockbuster, hubristic) was a gift of a different order rather than of a different magnitude: the quieter 'gift' of employee rights and welfare. Here, then, the virtual other of the actual philanthropy Bezos now funds is not quite a possible gift but the possibility of alleviating an ongoing situation: that of exploitative and demeaning labour conditions at Amazon warehouses. We thus register a shift from a shadow gift relation existing between proportions to one existing more flexibly between kinds or entities.

A BBC news article from 2019 provides an example that both exemplifies and complicates the argument so far presented. ${ }^{17}$ The focus was the achievement of Indian IT billionaire Azim Premji in becoming the country's most generous philanthropic giver. ${ }^{18}$ But recognition of the billionaire's largesse quickly gives way in the piece to commentary on the absence of giving by other members of the country's wealthy elite: indeed, the report is headlined, 'Why India's rich don't give their money away'. Premji may have 'seal[ed] his place among the world's top givers. But his generosity has put philanthropy in the spotlight in a country where charity does not appear to match wealth'. The disproportion is telling. As the author of a report on philanthropy in India puts it: 'If you look at those who have the money, they are not giving it'. Once more, what you see (the gift) is what you do not get: critique of the gift follows closely the gift itself. Premji, then, is framed as 'a magnanimous "outlier"' in the world of South Asian philanthropy as 'the first Indian billionaire to sign the Giving Pledge, an initiative by Mr Gates and Mr Buffet that encourages wealthy individuals to pledge half their fortunes to philanthropy'. In this way, the news item highlights a transparently proportional outlook on the gift alongside an array of reputed facts and figures about rates of Indian giving. But at the same time, ambiguity surfaces with a recognition that undercuts its argument: namely, that in this region 'many people give anonymously' - and it is indeed the

\footnotetext{
${ }^{15}$ https://www.vox.com/2018/9/13/17855950/jeff-bezos-donation-2-billion-philanthropy-charity-amazon-ceo The phrase 'bull run' here refers to the remarkable rise in Amazon share prices.

${ }^{16}$ The Guardian, 28 July 2017.

17 https://www.bbc.co.uk/news/world-asia-india-47566542, dated 2 April 2019.

${ }^{18}$ His firm, Wipro, is an icon of India's IT sector. Premji 'was just 21 when he dropped out of Stanford University to join Wipro, a company his father started in 1945. (He went back and finished school in 2000). Under him, Wipro, a refinery for vegetable oils, grew into one of India's biggest and most successful IT services firms' (ibid).
} 
case that a key genre of gifting in India is the gift that is given in secret. Claims such as 'India's rich do not give their money away' assume that giving is everywhere and always a visible act: that a gift, once given, can be known to have been given. Thus, while such secret giving might appear locally specific (a particular local gift modality albeit with various equivalents elsewhere), it reminds us that a shadow gift relation is a relation formed of the imagination: the relation is, indeed, shadowy, based frequently as it is on calculations comprising unknowable quantities. As we noted earlier, the totality out of which a gift emerges is imagined and therefore constitutively indeterminate (Sneath, Holbraad and Pedersen 2009: 24). Meanwhile, the actualised gift may be equally invisible and subject to speculative imagination. To reframe our earlier analytic, then: what you get is what you do not see.

So if, as we have been arguing, the gift (that is actually given) may form a model for a gift that could be, we might consider it also to be a form of prototype, with the actual intimating the possible. A prototype, as Corsín Jiménez (2014: 383) explains, has qualities of porosity and indefiniteness - and the gift that is haunted by another version of itself that may yet come to pass, rather like a prototype, is a 'thing-that-is-not quite-adequately-a-gift-yet'. And such uncertainty is even before the possibility of its being given in secret. The commentary on the case of Premji notes how a gift's visibility (and therefore knowledge of its quantity or kind or very existence at all) is far from being guaranteed, highlighting how the sorts of evaluation that allow for a gift to be conceptualised as being otherwise, prototypical or haunted rely on some sort of publicity, if not solid facts. And certainly, in India the gift given in secret (called gupt-dan) is a long-established and popular genre of giving that is particularly revered because it is immune from the immediate reward of an increase in a donor's public status, and people say that because of this the unseen reward which comes as merit or good karma will be greater' (Laidlaw 1995: 297). ${ }^{19}$ But while a gift given in true secrecy cannot be subject to morally-freighted public commentaries relating its actual and virtual versions, slippages between can and ought might figure nonetheless in a private giver's own moral calculus. If a friend runs the London Marathon for charity and I donate anonymously on their Just Giving webpage, the quantities donated by others are visible (with some contributors named and others anonymous). One's gift is given because of one's friendship and sense of the value of the charity being supported - but also in relation to the quantities on display, the resources that one has access to (and one's hopes and fears in respect of them), and one's sense of the appropriate level of compassion. In this way, we may discern both private as well as public hauntologies of the gift. Take as another example a debate on the issue of guilt and appropriate levels of giving hosted by a website specialising in securing and managing wealth. One contributor confesses: 'what I am struggling with right now is exactly the "great privilege = great responsibility" piece of the equation. I want to give back more and I'm trying to figure out how much we "should" be contributing to charity and other causes we believe in. We are high earners but also save quite a bit, live in a smaller house (in a walkable neighbourhood), have 1 car, etc. We have a lovely life, we just purposely design it to be on the frugal end of the spectrum. We have always given to charity but again I don't think we give enough, and that is why I am trying to figure out the right way to quantify this. Maybe it really is as simple as the $10 \%$ tithe

\footnotetext{
${ }^{19}$ See also Bercovitch (1994) on concealed exchanges in Papua New Guinea.
} 
concept (although to charities etc. vs. strictly to a religious organization)? Any thoughts appreciated...' ${ }^{20}$ The individual donating subject, then, who may or may not give in secret, is also apt to evaluate, question, reflect on and make judgments about his or her own giving practices.

According to Allen Buchanan, in Western ethical traditions 'both the kind and amount of aid [a person] renders and the choice of a recipient are left to the discretion of the individual. Thus you and I have a duty to aid the poor, but how we render aid, how much aid we render, and to whom among the poor we render aid is a matter of our choice' (1996: 99). Indeed, Buchanan continues, 'since one individual cannot be expected to aid all of the poor, the idea that duties to aid are "imperfect" makes perfectly good sense: It is up to the individual to choose what sort of aid to provide, how much of it to give, and upon whom to bestow it' (102). In theory, maybe. But, as we have seen, gifts in practice are often subject to evaluation both privately and publicly according to criteria of the possible - the idea that the gift could possibly be very different than it is, and that the moral force of the gift's virtual other might partake of the powers that could transform the world into something better (Guyer 2009: 362).

\section{Shadow gift relations and their temporalities}

A gift's potential, central to this essay, is a particular dimension of the gift's multifaceted temporal affordances. If temporal aspects of gift-giving have received analytical attention, the potential of the gift as a distinct aspect of the gift's temporal dimension remains underconceptualised. ${ }^{21}$ Potential, as we further discuss below, may be coercive, but it may also deal in the hopeful subjunctive: the gift might be other than that given. To explore this matter, we turn to a case study that draws on our long-term ethnographic research in north Indian blood donation and transfusion settings (conducted intermittently since 2003). The backdrop consists of longstanding but ill-organised state-led efforts to boost voluntary, nonremunerated blood donation in place of the predominant paid and family-replacement varieties, modes of giving considered by international arbiters of health policy, such as the WHO, to place transfusion recipients at heightened danger of infection and the relatives of patients under undue stress. ${ }^{22}$ The form of wealth given over, or shared here, then, is not money but rather blood. ${ }^{23}$ While a very different modality of gift from those discussed above, its focus on upliftment as a dutiful contribution to civic life, alongside its generality and anonymity (such gifts are directed untraceably to anyone in need), mean it might be glossed as 'expressive of charitable or philanthropic dispositions, and indeed be analysed as such' (Osella 2018: 8). For though the principal stated reason for the promotion of voluntary donation is the requirement to improve the safety of donated blood, its anonymity connects

\footnotetext{
${ }^{20}$ https://www.getrichslowly.org/guilt-of-wealth/

${ }^{21}$ See e.g. Derrida (1992) on gifts out of time, Bourdieu (2000) on the tactical timing of acts of giving, Strathern (2013) on intervals, sequencing, and revelatory instants in gift exchange, Ssorin-Chaikov's (2006) majestic study of heterochronic gifting practices in Soviet Russia, and Copeman (2005) on gifts of time.

22 In 'replacement' blood donation, relatives of recipients are asked to replace (in advance) the blood they require.

${ }^{23}$ See Street (2009), Carsten (2011) and Copeman (2009) on commonalities between money and blood.
} 
it to the kind of giving that is widely favoured in a host of other contexts both within and beyond India in which philanthropic action is considered to be both modern and moral only when directed untraceably to anyone in need. Indeed, both are pervaded by 'rhetorics of voluntarism' and a moral imagination in which 'a potential giver is connected to unknown others by means of anonymous, philanthropic skeins' (Simpson 2011: 273). The switch from a replacement to a voluntary mode of donation appears to instill blood donation activity with the anonymity and generality characteristic of this modernist philanthropic principle.

Normatively speaking, voluntary donations should take place according to a particular time map -- namely, repetition at three-month intervals (the hematological equivalent of a monetary standing order). This is in contrast to apparently less civic-minded blood donation modes: the potentially dangerous commercial transaction of 'professional' (the vernacular for paid or commercial) donation, and the one-time mode of family-replacement donation, performed in order to release blood for the benefit of one's immediate family member in need of transfusion. These modes of donation are thus characterized by different temporalities. A routine of dutiful, repetitive bloodshed structures voluntary blood donation's 'time of the civic' (Bear 2014: 27). Institutional medical demand for blood is continuous: the iterative presumption of a single voluntary blood donation in time is that it forms one of a series (Strathern 2017: 201). In Kockelman and Bernstein's (2012: 322) terms, voluntary blood donation foregrounds temporality as metricality: 'the repetition of tokens of a common event type'.

During our fieldwork, we found that promoters of voluntary blood donation enacted a temporal critique of the one-time replacement gift of blood. To reiterate: the one-time replacement gift is the long-standing norm of blood donation in India that the newer ideal of anonymous, voluntary giving seeks to supersede. The new ideal of anonymity - vouched for by global public health as safer and more efficient - characterizes the mode of one-time replacement as wasteful: gifts that could have been given, if repeated over time according to the ideal of four possible gifts per year, remain ungiven. Thus, if voluntary blood donation over time (preferably four times a year) represents the 'actualization of the potentials that are virtually present in our lives' (Mazzarella 2010: 723), one-time replacement giving represents the extinguishing of such potentials.

The figure of the ungiven gift of blood is an object of particular pathos and sentimentality in the field of blood banking in north India. This is because those tasked with promoting voluntary blood donation systematically translate the blood that remains ungiven into a logic of lives unsaved (which potentially could have been lives saved). These logics were captured at a training event for about 15 new voluntary blood donor recruiters that took place in one of Delhi's more modern blood banks, established in the early 2000s by an international charitable society. Each blood bank has an attached donor recruiter or 'social worker' whose tasks, unlike other blood bank staff, are non-technical. Instead, their work involves liaising with corporate, educational and religious institutions (churches, temples etc.) for the organization of blood giving events. More generally, they are also responsible for promoting voluntary blood giving as a positive, life-saving, community-building activity that does no harm to the donor. The problem is that many recruiters are just as fearful of 
donating their blood as the members of the public they are tasked with motivating. ${ }^{24}$ Trainers responsible for professionalizing blood donor recruitment seek to address this discrepancy with the aim of making recruitment activities more consistent and convincing.

One such trainer was a blood bank medic from a nearby town who also runs a small NGO promoting voluntary blood giving. He was concerned that blood donor motivation should not be 'just a job' for the trainee recruiters, but a deeply-held commitment. Successful recruiters were motivators of conviction, he told his audience. A centerpiece of the training workshop was a procedure of rhetorical mathematics in which, it was clear to us, the trainer was practiced. First of all, he went around the room gathering the ages of the trainees and the number of times they professed to having given their blood. Next, he wrote these figures on a whiteboard. There followed a public calculation of opportunity cost figures for each novice recruiter. Knowing the age of each recruiter allowed the trainer to calculate the maximum number of times they could have donated their blood, and to then subtract from that figure the number of actually performed donations in order to arrive at a total number of each trainee's opportunity cost, or phantom, blood gifts. For instance, a person who is 37 years old has been eligible to donate their blood for 19 years, i.e. since turning 18. Normally, 4 whole blood donations are possible per year. 19 years of eligibility to donate multiplied by 4 donations per year gives a figure of 76 possible donations. The number of actual donations was then subtracted from this figure.

But the trainer was not finished. The technology of blood component separation splits a single donated blood unit qualitatively and quantitatively into three transfusable units (made up of red blood cells, platelets and plasma, respectively). The procedure is carried out on donated blood units in a centrifuge machine in order to both better treat patients and preserve a scare resource. The technology is significant for it determines that the number of donations given is not the same as the number of 'lives saved'. Following from this, in a further dramatic numerical maneuver the trainer rhetorically tripled the numbers of lives not saved by each trainee: so, for instance, the above-mentioned trainee whose phantom gifts amounted to 70 (76 possible donations minus the 6 actually given), according to the arithmetic of component separation, in fact 'failed' to save the lives of 210 patients. The climax came when the trainer added together the trainees' individual ungiven gifts to arrive at an overall figure of well over a thousand 'unsaved' patients. The trainer thus spelt out to the trainees the partonomic relation between their given donations and those remaining ungiven as an act of criticism, with that which has been given not being subject to acclaim but instead only serving mathematically to underscore that which has not. However tendentious such an exercise of the arithmetical shaming of trainees might be ${ }^{25}$, its

\footnotetext{
${ }^{24}$ See Copeman and Banerjee (2019) on fears widespread in South Asia concerning blood donation as an irrecoverably depletive activity.

${ }^{25}$ The assumptions reflected in the exercise do not bear close scrutiny since although there is a shortage of blood in terms of stock levels adequate for a conventional voluntary system, since the system in practice is mixed - comprising voluntary, replacement, paid and even directed donations -- it is difficult to determine how often patients in fact die for want of blood. Moreover, many doctors ask blood banks for whole blood rather than components, so the assumption that donations are 'tripled' via their division into three is more a counterfactual rhetorical device than an objective calculation of opportunity costs. Further, each transfusion, at least in theory, is made up of more than a single unit - so in a double sense, then, it is rarely if ever a case of
} 
rhetorical effect was very much evident, with several of them moved to tears. To reiterate: a donation not given, which separated into components would save three, translates into a logic of lives not saved. A hauntology of the gift, indeed; in which, again, it is the gap between the given and ungiven in which critique resides or through which critique is generated.

The trainer's intention of inculcating embodied consistency between the role and person of trainees thus drew on an interactive methodology of making explicit the possible number of recipients of ungiven donations: relying on the ubiquity of the equation (rhetorical rather than actual) in the donor recruitment field between quantity of donations made and number of lives 'saved', the trainer effectively conjures the ghostly magnitude of the unsaved. Since, in this particular case, the ungiven and the unsaved run together so closely, we find in it the hauntedness of the gift at its highest pitch. Through a morally loaded practice of numerical pedagogy - a kind of critical quantification of the shadow gift relation - the truths of the urgency of the recruiter's task, and that of the need for constancy in pursuing it, are established.

\section{The tyranny of the (potential) gift?}

In the above discussion we saw how a trainer in Delhi maps phantom gifts according to a set of temporal particulars, with trainees' ages and dates of birth measured against a rhythm of four possible blood gifts per year. In order for the relation between the given and the withheld to be invoked as the basis of moral commentary (here, by the trainer) - as thwarted potential - we see how the ungiven gift remains ungiven in time. Thus, a specific species of temporal politics arises, which we unpack with reference to recent anthropological writing on potential. Indeed, the sense that a gift might (auto)critique by way of its shadow relation with a virtual, ungiven form of itself illuminates well the political dimension of potential (Taussig, Hoeyer and Helmreich 2013).

Taussig, Hoeyer and Helmreich (2013: 6) call attention to how articulations of potential are imbricated with the political in making claims on individuals to behave in particular ways; namely, to act in a manner that may be said to fulfil that potential: as we noted earlier, 'can' comes to imply 'ought'. Such claims may take the form of moral injunctions. The authors give the example of a biobank articulated as having the potential to transform biomedicine. Given such potential, it becomes morally incumbent on medical or state authorities to fund it. We see, they argue, 'how naming and framing something in terms of potential has political effects in the world' (10). In the same collection, Sharon Kaufmann (2013) describes the coercive effects such invocations can have as 'the tyranny of potential'. In the US cases she describes, since it is now possible to actualise the potential for longevity via living kidney donations, the matter becomes a fait accompli: the passing into common sense of the notion of the 'spare' kidney makes it all-too-donatable - for instance, by the young to

one donated unit saving one life. Finally, many transfusions form just a part of larger treatment regimes and so are often not obviously isolable as 'lifesaving' in a discrete sense. 
the old (Kaufman [2013: 60] calls this 'donating up the generations'). New potentials result in new obligations, however biologically intrusive and possibly damaging the actualised reality may be for donors. To translate the cases analysed by Kaufman into the conceptual approach we have been developing in this essay, we might say that the potential that medics and others ascribe to this modality of biomedical gift creates phantoms out of ungiven kidneys. Once more, the ungiven gift, as unactualized potential, is a form of critique.

This example is significant because it allows us to finesse our understanding of the potential gift. The shadow gift relation as a (critical) technology of the imagination can be variably put to use. On the one hand, the virtual other of the actual gift might be experienced as 'the vice-like grip of duty's iron fist' (Edelman 2004: 159) - an oppressive, coercive, possibly depletive ought. On the other, it might serve to highlight unjust hoarding, avaricious withholding and the conceitedness of the gift as given ${ }^{26}$ - arguably a necessary, beneficent ought. Inevitably, whether the relation is considered to have effects that are tyrannical or valuable will be dependent on the evaluator's structural position, with the two versions of ought just noted either not self-evidently one or the other or simply assessed differently by different parties. From our point of view, the case of the blood donor recruiters discussed earlier shares features with Kaufman's analysis of the tyranny of potential, with the mathematical exercise and units of blood that have been given only serving to call attention, by obviation, to the units that could have given but were not. The virtual gift haunts the given one: because more blood donations could have been given, they should have been given, too. Virtual gifts are deployed to induce shame within those who arguably have no reason to feel it - withholding essentially being made to equate with manslaughter. (Of course, from the trainer's point of view, his approach is defensible as being in the service of the higher goal of self-consistent donor recruiters, and ultimately, the saving of lives).

But equally, certain moral obligations are, of course, entirely necessary and desirable. If potentiality implies that things could be other than they are, it is the same subjunctive quality that implies that a gift could be other than it is (i.e., other than that given) - in the sense of positive possibility, or legitimate critique of the withholding of aid or assistance. For example, in our view it is less easy to locate the tyranny of the potential gift in the following example in which the virtual gift is conjured as a simple plea for fairness. In an earlier paper (Banerjee and Copeman 2018), also drawing on our north Indian fieldwork, we described activist responses to the Bhopal Gas Disaster of $1984 .{ }^{27}$ There we analysed a species of gift that activists intentionally cause to be haunted by a gift that has been withheld - that of state medical assistance and medical care. Very briefly: the Indian government has failed to provide adequate healthcare to the survivors of the disaster, refusing to prosecute the corporations responsible or recognize obvious signs of secondgeneration effects and also failing to deliver upon promises of public medical research into

\footnotetext{
${ }^{26}$ See Copeman and Banerjee (2019: 227-228) for a striking example of this.

${ }^{27}$ In 1984, a poisonous cloud of methyl isocyanate leaked out of a negligently maintained Union Carbide plant in Bhopal. Over the course of the night, the gas cloud quickly engulfed the slum settlements that surround the factory, leading to the immediate death of over two thousand. The disaster overwhelmingly affected the marginalized inhabitants of the city that lived in squatter settlements and worked in the informal economy.
} 
the chronic effects of this poisoning. In one of several strategies employed, activist children ask volunteers to cut out large paper hearts of various colours and pen a letter on them to the prime minister. The name of the campaign gives away its affective ploy. The 'Have a Heart, Prime Minister' campaign is built on the idea that these carved hearts are donations to the prime minister to be transplanted for his obviously missing organ. If his heart were indeed in its place, it would not allow him to turn a deaf ear to the suffering of the activistchildren. The gift of the heart (again) is indicative of the 'gift' not given - that of state assistance and medical care. For these activists the emphasis, once more, is not on what a

gift is but on what a gift should be, and the mechanism for conjuring such a virtual gift is precisely a gift (albeit a pseudo one). So whereas in the earlier case it was the trainer's commentary on the (non)gifts of others that brought to light the phantom or virtual gifts that were not (but could have been) given, what we find in the Bhopal case is the intentional haunting by the givers themselves of their (pseudo-) gifts by an 'otherwise' form. We can thus begin to appreciate the dynamic flexibility of the virtual gift as a critical modality. Gifts given conjure gifts ungiven, but the subject position of the commentator cannot be pre-determined. In each case, however, activist critique operates by calling forth (imagining) a virtual gift in the sense of the virtual we defined earlier as 'a potential which serves to constantly bring new "actual" entities into being' (Bialecki 2012: 307). At least, that is what is intended: what we have called the shadow gift relation between the given and non-given - operationalized critically - is intended to lead blood donor recruiters to donate blood more frequently and also to encourage the Indian Prime Minister to keep his promise to give medical and financial assistance to Bhopal survivors. That is, the virtual gift is intended to bring new 'actual' gifts into being. We thus see the dynamic flexibility that characterises how a charitable gift may act as an incitement to critical discourse (commentary, evaluation) and become subject to moral judgements.

\section{Conclusion}

The charitable gift, this essay has tried to show, is well capable of narrating both its own and others' giving infelicities. We can speculate about whether we could ever find a charitable gift that was ever fully itself, present or 'settled' -- a gift that would be neither subject to nor an agent of criticism. Even in the unlikely event that a public charitable donation was judged to be of adequate proportions and kind, and therefore not itself open to critique, such a donation would, through contrastive perception, be all the more equipped for critiquing other public gifts deemed infelicitous in precisely those aspects. As the Gospel of Luke put it:

Just then he looked up and saw the rich people dropping offerings in the collection plate. Then he saw a poor widow put in two pennies. He said, 'The plain truth is that this widow has given by far the largest offering today. All these others made offerings that they'll never miss; she gave extravagantly what she couldn't affordshe gave her all!'

Luke 21:1-4 
Key to our analysis here has been acknowledging that which remains ungiven. Weiner's paper 'Inalienable wealth' (1985) succinctly lays out her argument concerning the salience of that which is kept back. For Weiner, 'the object rather than the act of reciprocity plays the dominant role' (211). Similarly focusing on the object and how forms of wealth may be kept back, we have also sought to analytically expand the kind of relations exchange comprises. Like Weiner we have been concerned with "keeping things instead of giving them away' (Weiner 1985), but also with imagined relations between that that which is given and that kept, or between that which is given and that which could be or might have been given.

This brings us back to questions of pathos and critique: pathos, because thinking about the gift that is given in relation to the potential for something else to have been given discloses limits and constraints in social relations (see Simmel 1971); critique, because what might have been given is capable of placing into critical relief the nature of what actually is. To pay attention to the otherwise of giving is to notice how the actually given, in relation to that which remains ungiven, provokes commentaries composed of critical reflection and moral evaluation that are frequently marked by consequential slippages between 'can' and 'ought'. The shadow gift relation is the shape taken by the gap between how things are and how they ideally ought to be in contexts of gift transfer: a critical haunting of the 'is'-gift by its alternative virtual modalities. Weiner rightly notes that 'The value created by keeping must be seen in relation to the constant threats and needs of giving' (224). If she was able to advance anthropological theory of the gift through scrutinizing this relation in terms of alienability, we suggest it can be elucidated further by examining it spectrally: the gift that exists beyond the living present, beside itself.

Giving is also keeping (withholding). The relation between these elements of an act of giving is neither inert nor is it, so to speak, given. Giving is thus a technology of the imagination because it is a process which precipitates the imagination of a relation between an actual/visible/present gift and a double that is virtual/invisible/absent but nonetheless real because it exists in the form of a 'manifold of potentials for how [the gift] could be' (Holbraad, Pedersen, and Viveiros de Castro 2014) and that might indeed be realised. Hence the critical possibilities of a gift: an effect of the shadow gift relation, which means that a gift is never just itself, but always potentially something else as well.

Such a shadow gift relation between the gift as given and its virtual others is central to the moral evaluation of giving episodes, with could be or could have been gifts invoked as a force of rhetoric in assessing appropriate levels of commitment and as instruments of intervention in public debates about levels and kinds of giving. Lauren Berlant (2004: 10) asks: 'What is the relation between becoming capaciously compassionate and becoming distant from responsibility for what one experiences directly and indirectly about the populations relegated to social negativity? What if it turns out that compassion and coldness are not opposite at all but are two sides of a bargain that the subjects of modernity have struck with structural inequality?' This essay has shown that such a relation between capacious compassion and distance from responsibility is present within the ideation of a 'single' gift - the two sides of the same gift. It has also sought to show how acknowledging the imagined relation between the actually given and an ungiven that haunts it is important for understanding how potential operates as a powerful political dimension in contexts of 
charitable giving. Signalling that the possibility of a different gift exists is the first step in eventuating such a gift. Moving such a gift into the actual domain from the virtual one may well be entirely necessary (see e.g. the case of Bhopal discussed above). Yet virtual modes of donation resist easy moral accounting, for the possibility of a gift - as scholarship on biological forms of gift has shown with particular vividness - can also lead to an irresistible sense that it must be given, that if acted upon, might be far from being in the donor's own interests.

\section{References}

Amsterdam AG and Bruner J (2000) Minding the Law. Cambridge, MA: Harvard University Press.

Banerjee D and Copeman J (2018) Ungiven: Philanthropy as Critique. Modern Asian Studies 52(1): 325-350.

Bear L (2014) Doubt, Conflict, Mediation: The Anthropology of Modern Time. Journal of the Royal Anthropological Institute (N.S.) 20(S1): 3-30.

Beldo L (2014) The Unconditional 'Ought': A Theoretical Model for the Anthropology of Morality. Anthropological Theory 14(3): 263-279.

Bercovitch E (1994) The Agent in the Gift: Hidden Exchange in Inner New Guinea. Cultural Anthropology 9(4): 498-536.

Berlant L (2004) Introduction: Compassion (and Withholding). In: Berlant L (ed) Compassion: The Culture and Politics of an Emotion. New York and London: Routledge, pp. 1-13. Bialecki J (2012) Virtual Christianity in an Age of Nominalist Anthropology. Anthropological Theory 12(3): 295-319.

Bialecki J (2018) Judgment and Critique, Anthropology and Religion. Critical Research on Religion 6(1): 10-15

Boland T (2013a) Towards an Anthropology of Critique: The Modern Experience of Liminality and Crisis. Anthropological Theory 13(3): 222-39.

Boland T (2013b) Critique as a Modern Social Phenomenon: The Critical Society. New York: Edwin Mellen Press.

Boltanski L (2010) De la critique. Précis de sociologie de l'émancipation. Paris: Gallimard. Bourdieu P (2000) Pascalian Meditations. Stanford: Stanford University Press.

Buchanan, A (1996) Charity, Justice, and the Idea of Moral Progress. In: Schneewind JB (ed) Giving: Western Ideas of Philanthropy. Bloomington: Indiana University Press, pp. 98-116. Carsten J (2011) Substance and Relationality: Blood in Contexts. Annual Review of Anthropology 40: 19-35.

Copeman J (2005) Veinglory: Exploring Processes of Blood Transfer Between Persons. Journal of the Royal Anthropological Institute (N.S.) 11(3): 465-85.

Copeman J (2009) Veins of Devotion: Blood Donation and Religious Experience in North India. New Brunswick, NJ: Rutgers University Press. 
Copeman J (2018) Exposing Fakes. In: Copeman J and da Col G (eds) Fake: Anthropological Keywords. Chicago: Hau Books, pp. 63-90.

Copeman J and Banerjee D (2019) Hematologies: The Political Life of Blood in India. Ithaca:

Cornell University Press.

Corsín Jiménez A (2008) Well-Being in Anthropological Balance: Remarks on Proportionality as Political Imagination. In: Corsín Jiménez A (ed) Culture and Well-Being: Anthropological Approaches to Freedom and Political Ethics. London: Pluto Press, pp. 180-197.

Corsín Jiménez A (2013) An Anthropological Trompe L'Oeil for a Common World: An Essay on the Economy of Knowledge. Oxford: Berghahn.

Corsín Jiménez A (2014) Introduction: The Prototype: More Than Many and Less Than

One. Journal of Cultural Economy 7(4): 381-398.

Davis J (1992) Exchange. Minneapolis: University of Minnesota Press.

Deleuze G (1988) Bergsonism, Tomlinson H and Habberjam B (trans). New York: Zone Books. Deleuze G and Parnet C (2007) Dialogues II. New York: Columbia University Press.

Derrida J (1992) Given time: I. Counterfeit Money, Kamuf P (trans). Chicago: University of Chicago Press.

Derrida J (1993) Spectres of Marx: The State of the Debt, the Work of Mourning and the New International. London: Routledge.

Edelman L (1994) Compassion's Compulsion. In: Berlant $L$ (ed) Compassion: The Culture and Politics of an Emotion. New York and London: Routledge, pp. 159-186.

Fox RC and Swazey J (1992) Spare Parts: Organ Replacement in American Society. New York: Oxford University Press.

Godelier M (1999) The Enigma of the Gift. Cambridge: Polity.

Guyer J (2009) On 'Possibility': A response to 'How is Anthropology Going'. Anthropological Theory 9(4): 355-370.

Holbraad M, Pedersen MA, and Viveiros de Castro E. (2014) The Politics of Ontology:

Anthropological Positions. Theorizing the Contemporary, Cultural Anthropology website, January 13, 2014. https://culanth.org/fieldsights/462-the-politics-of-ontology-

anthropologicalpositions.

Jameson F (1999) Marx's Purloined Letter. In: Sprinker M (ed) Ghostly Demarcations: A Symposium on Jacques Derrida's 'Spectres de Marx'. London and New York: Verso, pp. 2667.

Kaufman SR (2013) Fairness and the Tyranny of Potential in Kidney Transplantation. Current Anthropology 54(S7): S56-S66.

Kelly A (2003) Organizing A Clinical Trial: Intervention, Translation, and Generalization at the Intersections of Scientific Knowledge. MPhil Thesis, University of Cambridge, UK.

Kockelman, P, and Bernstein A (2012) Semiotic Technologies, Temporal Reckoning, and the Portability of Meaning. Or: Modern Modes of Temporality-Just How Abstract Are They?

Anthropological Theory 12(3): 320-48.

Ladd J (1957) The Structure of a Moral Code: Navajo Ethics. Cambridge, MA: Harvard University Press.

Laidlaw J (1995) Riches and Renunciation: Religion, Economy, and Society among the Jains. Oxford: Clarendon Press.

Laidlaw J (2000) A Free Gift Makes No Friends. Journal of the Royal Anthropological Institute 6: 617-634. 
Mazzarella W (2010) The Myth of the Multitude, or, Who's Afraid of the Crowd? Critical Inquiry 36(4): 697-727.

Osella F (2018) Charity and Philanthropy in South Asia: An Introduction. Modern Asian Studies 52(1): 4-34.

Simmel G (1971) On Individuality and Social Forms. Chicago: University of Chicago Press. Simpson B (2011) Blood Rhetorics: Donor Campaigns and Their Publics. Ethnos 76(2): 254275.

Sneath D, Holbraad M and Pedersen M (2009) Technologies of the Imagination: An Introduction. Ethnos 74(1): 5-30.

Ssorin-Chaikov N and Sosnina O (2004) The Faculty of Useless Things: Gifts to Soviet Leaders. In: Heller K and Plamper J (eds) Personality Cults in Stalinism / Personenkulte im Stalinismus. Göttingen: Vandenhoeck and Ruprecht, 277-300.

Ssorin-Chaikov N (2006) On Heterochrony: Birthday Gifts to Stalin, 1949. Journal of the Royal Anthropological Institute 12(2): 355-75.

Strathern M (2017) Afterword. Journal of the Royal Anthropological Institute (N.S.) 23(S1): 166-81.

Street A (2009) Failed Recipients: Extracting Blood in a Papua New Guinean Hospital. Body \& Society 15(2): 193-215.

Surralles A (2016) On contrastive perception and ineffability: assessing sensory experience without colour terms in an Amazonian society. Journal of the Royal Anthropological Institute (N.S.): 1-18

Taussig K-S, Hoeyer K, and Helmreich S (2013) The Anthropology of Potentiality in Biomedicine: An Introduction to Supplement 7. Current Anthropology 54(S7): S3-S14. Thane $P(2018)$ The rollback of the state has created levels of poverty last seen in the UK in the 1900s. New Statesman, 24 October.

https://www.newstatesman.com/politics/economy/2018/10/rollback-state-has-createdlevels-poverty-last-seen-uk-1900s

Thornton C (2017) The Headed Meronomy as a Ladder to Complex Thought. Draft. Townsend C (2017) I Speak Therefore I Am: On Daniel Heller-Roazen's 'No One’s Ways'. Los Angeles Review of Books, May 31.

Tversky B (1989) Parts, Partonomies, and Taxonomies. Developmental Psychology 25(6): 983-995.

Weiner AB (1985) Inalienable Wealth. American Ethnologist 12(2): 210;227.

Weiner AB (1992) Inalienable Possessions: The Paradox of Keeping-while-Giving. Berkeley: University of California Press.

Yan Y (2005) The Gifts and Gift Economy. In: Carrier J (ed) A Handbook of Economic Anthropology. Cheltenham: Edward Elgar Publishing, pp. 246-261. 